Jejak Vol 12 (1) (2019): 204-217 DOI: https://doi.org/10.15294/jejak.v12i1.19516

\title{
Willingness to Pay to Overcome Pollution in Tapak River, Semarang
}

\author{
Indah Susilowati ${ }^{1 凶}$, Hasmi Nurdinsyah Malik², A'yuni Choirunnisa3, Farah Aisha Nur Afifah ${ }^{4}$, \\ Ulfatun Niswah ${ }^{5}$
}

12345Universitas Diponegoro, Semarang

Permalink/DOI: https://doi.org/10.15294/jejak.v12i1.19516

Received: October 2018; Accepted: January 2019; Published: March 2019

\begin{abstract}
This study aims to analyze the level of Willingness to Pay of the community around TapakTugurejo Village, TuguSubdistrict, Semarang City in pollution prevention efforts on the Tapak River. This study offers a water purification model with the slow sands filtration method to improve water quality on the Tapak River. The analysis used was hypothetical market, Contingent Valuation Method (CVM), and multiple linear regression analysis to determine the Willingness to Pay relationship with other influencing factors, such as income, education, and age. Data was obtained from 30 respondents who were residents in RW04 TapakTugurejo Village, Semarang. Sample collection used in this study was the strategic random sample method. Hypothetical Market Value of respondents determines the willingness to pay for river pollution prevention efforts. The results found that the average cost of willingness to pay (WTP) of respondents for river pollution prevention activities from 30 respondents was Rp. 14,000.00. The total cost of WTP per year must be paid by the community from the loss of mangroves in the Tugurejo Village with a population of 6,941 people, was Rp 97,174,000.00.
\end{abstract}

Key words : Slow Sand, Tapak Rive, WTP

How to Cite: Susilowati, I., Malik, H., Choirunnisa, A., Nur Afifah, F., \& Niswah, U. (2019). Willingness to Pay to Overcome Pollution in Tapak River, Semarang. JEJAK: Jurnal Ekonomi dan Kebijakan, 12(1), $204-217$. doi:https://doi.org/10.15294/jejak.v12i1.19516 


\section{INTRODUCTION}

Rivers have an important role in life. The existence of river ecosystems can provide benefits for living beings. However, destructive human activities can adversely affect the quality of rivers. For example, industrial activities that use the river as a waste disposal site. These activities will certainly have an impact on the decline in water quality, due to changes in physics, chemistry and biology. Polluted river conditions also cannot be used for fishing activities (Salmin, 2005).

The monitoring results of the Ministry of Environment in 2014-2017 showed that water quality in Indonesia in the past four years tended to decline, especially in the Java and Sumatra regions. This decrease is indicated by an increase in the percentage of the number of river monitoring points with a heavily polluted status, which can be seen in Figure 1. Figure 1 shows that in 2014 as many as $59.9 \%$ of river monitoring points in Indonesia were heavily polluted, the number decreased in 2015 to $45.8 \%$. In 2016, it increased to $62 \%$. After that, it increased to $75 \%$ in 2017. The source of river pollution came from domestic activities measured by the proportion of Biochemical Oxygen Demand (BOD) and Chemical Oxygen Demand (COD) as well as coliform content. River water quality in most provinces also has organic content that exceeds the value of quality standards (represented by COD parameters). Based on Government Regulation Number 82 of 2001, which is equal to $25 \mathrm{mg} / \mathrm{l}$ (KLH, 2012).

Tapak River is one of the rivers that has an important role in the city of Semarang. Apart from being a supporter of community activities around the river, the Tapak River is also used to support agricultural activities and pond fisheries. On the other hand, the Tapak River is also used for industrial activities as a waste disposal site.

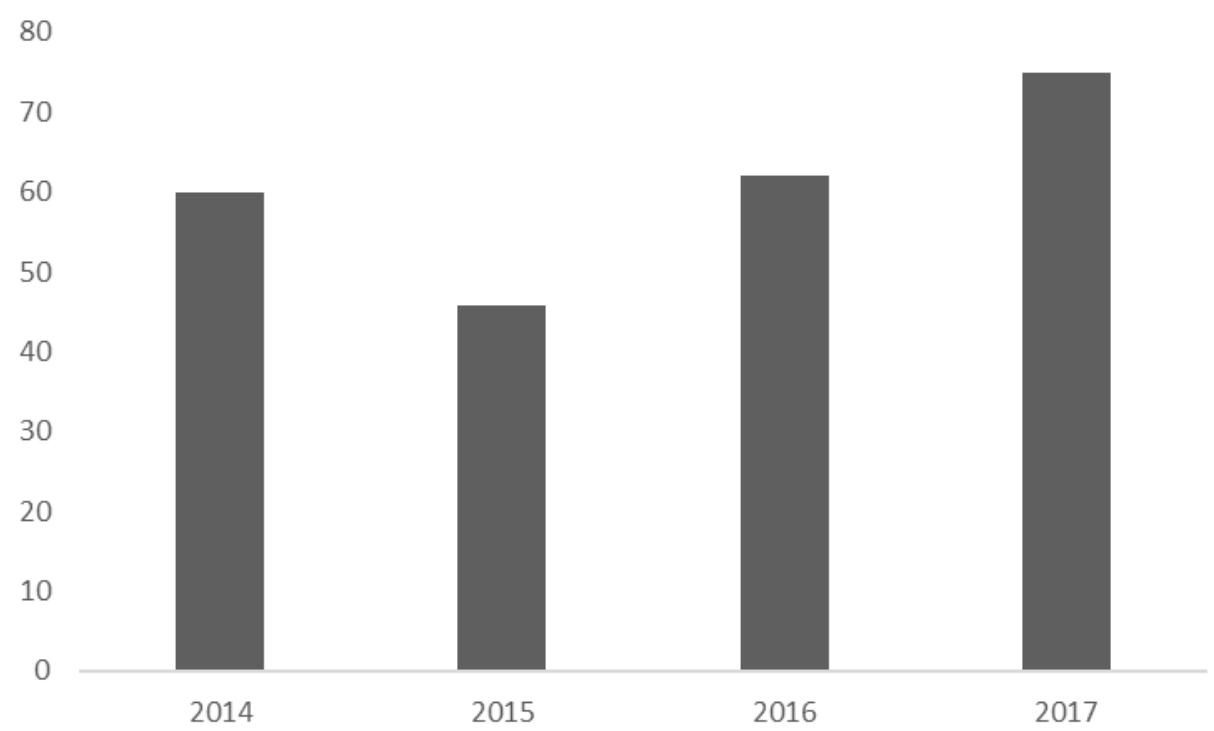

Figure 1. Percentage of River Monitor Points in Indonesia with Heavy Polluted Status for 20142017

In general, Tapak River is only used for agricultural irrigation of community. But in the upstream area during the dry season, when the artistic water of the community 
experiences drought, washing activities and the need for toilet washing (MCK) are still being carried out. The use of the Tapak River, which varies from upstream to downstream, causes household waste which is also a major source of pollution along the river. Pollution levels can be known through BOD and COD test results according to water quality standards. The level of water pollution in the Tapak River can be seen based on criteria according to Government Regulation No. 82 of 2001 in Table 1.

Table 1. BOD and COD Test Criteria

\begin{tabular}{|c|c|c|c|c|c|c|c|c|}
\hline \multirow[t]{2}{*}{ No } & Parameter & \multirow[t]{2}{*}{ Unit } & \multirow[t]{2}{*}{$\begin{array}{l}\text { Analysis } \\
\text { Results }\end{array}$} & \multirow[t]{2}{*}{$\begin{array}{l}\text { Reference } \\
\text { Method }\end{array}$} & \multicolumn{4}{|c|}{$\begin{array}{l}\text { Government Regulation Number } 82 \text { of } \\
2001 \text { (class) }\end{array}$} \\
\hline & PHYSICS & & & & I & II & III & IV \\
\hline 1 & $B O D_{5}$ & $\mathrm{mg} / \mathrm{l}$ & 35 & $\begin{array}{l}\text { SNI-o6- } \\
6989 \cdot 72- \\
2009\end{array}$ & 2 & 3 & 6 & 12 \\
\hline 2 & COD & $\mathrm{mg} / \mathrm{l}$ & 69,481 & $\begin{array}{l}\text { SNI-o6- } \\
6989.15^{-} \\
2009\end{array}$ & 10 & 25 & 50 & 100 \\
\hline
\end{tabular}

The results of the Environmental Office research show that the Tapak River downstream has a COD of 69,481. Referring to Table 1, the Tapak River is in the class III classification group with a range of $50-100$. In accordance with Government Regulation Number 82 of 2001 concerning the Management of Water Quality and Water Pollution Control, class III classification shows that water can only be used for irrigating plants, other designation, meaning that water quality is not good for consumption. Whereas for the Tapak River BOD data obtained is 35 , indicating that the Tapak River is classified as a polluted category which certainly cannot be consumed.

River pollution can cause health problems. Therefore, efforts need to be made to reduce the level of pollution so that the river conditions do not worsen. One method that can be applied is slow sand filtration, which is the process of purifying water through a pile of porous sand to reduce the content of organic and pathogenic organisms. Water is directed through a filter in the form of fine sand, gravel and stone. Communities have a central role in tackling river pollution.
To reduce pollution in the Tapak River, communities around the watershed need to be involved. The willingness of the community to pay (Willingness to Pay) is the capital to realize the solution. Broadly speaking, Willingness to Pay (WTP) can be interpreted as a measure of the maximum number of people to sacrifice goods / services to obtain other goods / services (Fauzi, 2010). WTP are influenced by several variables, such as age, sex, income, number of household members, education, main source of drinking water, and status of home ownership to determine the willingness of the community to pay (Ningrum, 2018).

Contingent Value Method (CVM) is a survey-based method that can be used to calculate WTP values. Technically, CVM can be practiced in two ways, namely experimental techniques and surveillance techniques. Basically, the CVM method is used to find out the desire to pay the community to improve environmental conditions and the desire to receive compensation due to environmental damage (Ladiyance and Yuliana, 2014). 
The survey was conducted along the Tapak River to find out the value of the WTP of respondents to the existence of a river water quality improvement program. The purpose of this research is to identify the source of pollution in the Tapak River, how much the willingness to pay from the community in the Tapak River area for the prevention of water pollution, and the analysis of factors that can affect the value of WTP.

\section{RESEARCH METHOD}

This study employed statistics descriptive to process the primary and/ or the secondary data. The primary data was obtained by conducting interviews directly and the secondary data sourced from journals and literature. The sampling technique is done by the strategic random sample method, where all houses around the Tapak River will be divided into several blocks and randomly sampled on each block. Interviews were conducted directly on respondents who resided around the Tapak River in order to obtain information in the form of data based on research indicators. 30 people who lived in RWo4 Tugurejo Urban Village, Tugu Subdistrict, Semarang City to be interviewed as a research sample. Because respondents have different characteristics, it is necessary to have certain standards to measure them, standard variables can be explained more detail through Table 2. This study uses the Contingent Valuation Method (CVM) method. This method is used to determine the Willingness to Pay (WTP) of people who carry out activities around the Tapak River. Furthermore, in this study also used the method of multiple regression analysis with the enter method used to determine the relationship between factors that influence the value between WTP. In the proposed questionnaire, there are several questions relating to the socio-economic conditions of the respondents including: age, gender, number of family members, presence / absence of activity, income level, and water quality level (Mitchell and Carson, 1989; Choe, K, et. al, 1996).

In addition, further information will be asked about the water quality of the Tapak River and their activities around the river. To illustrate the opinions of the community about the water quality of the Tapak River three scales were used; 1 ). Clear and odorless; 2). Smells and looks cloudy; 3). Dirty and visible rubbish mound. To describe the water quality of the Tapak River respondents were asked to choose between level 1 to 3 . In the next stage, respondents will be asked questions about the willingness to pay a certain amount in one month, to help fund the river water quality improvement program. The amount to be paid ranges from 5,000 to 20,00o rupiah per month. This study aims to estimate the value of river water quality improvement and to determine the socio-economic factors that determine this value. This study uses three types of estimates: 1). Simple average. The expected willingness to pay (EWTP) is the average money spent by respondents based on the survey. (Choe at.al., 1996; Nam and Son, 2005). To measure the non-market economic valuation, the value of the existence of a natural resource can use the CVM method (Fauzi, 2010). There are several stages in conducting studies using the VCM method, as stated by Splash and Hanley (1993) in Lasonci (2012). 
Table 2. Operational definitions of variables

\begin{tabular}{|c|c|c|}
\hline Variable & Definition & Value \\
\hline $\begin{array}{l}\text { Willingness } \\
\text { to Pay (WTP) }\end{array}$ & $\begin{array}{l}\text { Possibility of someone's } \\
\text { willingness to pay (WTP) in order } \\
\text { to overcome river pollution. This } \\
\text { variable is measured using a } \\
\text { dummy variable, namely } 1 \text { for the } \\
\text { decision to be willing to pay for } \\
\text { river pollution prevention costs, } \\
\text { and o for the decision not to pay } \\
\text { the cost of controlling river } \\
\text { pollution. (Hanley and Spash, } \\
\text { 1993) }\end{array}$ & $\begin{array}{l}\mathbf{1}=\text { Willing } \\
\mathrm{o}=\text { Unwilling }\end{array}$ \\
\hline $\begin{array}{l}\text { Offer Amount of WTP } \\
\text { Value (Rupiah) }\end{array}$ & $\begin{array}{l}\text { The amount of the bid is } \\
\text { proposed to pay for the } \\
\text { prevention of river pollution. } \\
\text { (Hypothetical market) }\end{array}$ & $\begin{array}{l}\text { Rp 10.000,00 / year } \\
\text { Rp 15.000,00 / year } \\
\text { Rp 20.000,00 / year }\end{array}$ \\
\hline Sex & Biological status of a person. & $\begin{array}{l}\mathbf{1}=\text { Male }(\mathrm{M}) \\
\mathbf{2}=\text { Female }(\mathrm{F})\end{array}$ \\
\hline $\begin{array}{l}\text { Age } \\
\text { (Year) }\end{array}$ & $\begin{array}{l}\text { The life span of respondents from } \\
\text { birth to research is calculated } \\
\text { from the last anniversary proven } \\
\text { with a KTP or birth certificate. }\end{array}$ & $\begin{array}{l}\text { Number } \quad \text { Variable } \quad \text { (metrics } \\
\text { scale) }\end{array}$ \\
\hline $\begin{array}{l}\text { Income } \\
\text { (Rupiah) }\end{array}$ & $\begin{array}{l}\text { Respondent's income obtained } \\
\text { from the main or side job. }\end{array}$ & Number Variable \\
\hline $\begin{array}{l}\text { Education } \\
\text { (Year) }\end{array}$ & $\begin{array}{l}\text { The education levels of } \\
\text { respondents range from }\end{array}$ & $\begin{array}{l}<6 \quad=\text { Not graduating in } \\
\text { Elementary School }\end{array}$ \\
\hline & $\begin{array}{l}\text { elementary school to college } \\
\text { level. }\end{array}$ & $\begin{array}{l}6 \quad=\text { Elementary School } \\
<9 \quad=\text { Not graduating from } \\
\text { Junior High School } \\
9=\text { Junior High School }\end{array}$ \\
\hline & & $\begin{array}{l}<12 \quad=\text { Not graduating from } \\
\text { Senior High School } \\
=\text { Senior High School } \\
>12=\text { Perguruan Tinggi }\end{array}$ \\
\hline
\end{tabular}

The hypothesis built in this study is that the community makes an effort to tackle pollution on the Tapak River. Community contributions and related parties are needed to support the development of river.
Pollution by providing monthly contributions. The money from the contributions will later be used for the construction of water purification facilities using the slow sand filtration method. The 
offer of the amount of Willingness to Pay (WTP) to support the prevention of river pollution by the slow sand filtration method. This offer consists of two scenarios offered to people who live around the Tapak River environment.

To calculate the average value of a WTP we must pay attention to whether there is a very deviant average value or not. If there is a deviant average value, then it can use the median value. If there is not, then use the average value using equation (1):

$\mathbf{E W T P}=\frac{\sum_{i=1}^{\mathrm{n}} W i}{N}$

Information:

EWTP $=$ ExpectedWTP

$W W_{i i}=i-$ WTP respondent

$n n \quad=$ Total respondents

ii $\quad=i$ - respondent

The estimated total value of WTP can be obtained using equation (2):

$$
\mathbf{T W T P}=\sum_{i=1}^{n} W_{i}\left\{\frac{n_{i}}{N}\right\} P .
$$

Information:

$$
\begin{aligned}
\text { TWTP }= & \text { Total WTP } \\
W W_{i i}= & i-\text { WTP respondent } \\
n n \quad= & \text { The total sample of } i \text {-respondent } \\
& \text { who are willing to pay as much as } \\
& \text { WTP } \\
N N \quad= & \text { Total sample } \\
P P \quad= & \text { Total population } \\
i i \quad= & \text { respondent }-i \text { who is willing to pay } \\
& (i=1,2,3, \ldots, \mathrm{n})
\end{aligned}
$$

The test of multiple linear regression statistics with the enter method is used to find out what factors affect the value of the WTP. Regression is done using Eviews 9 software. Three independent variables are used in this analysis, namely age, education duration, and income, which is expected to affect the dependent variable, namely the value of WTP. The regression equation for WTP values in this study are as follows:

$W T P=\beta o+\beta_{1} F U i+\beta_{2} L P i+\beta_{3} P d i$.

Information:

$W T P=$ Respondent's WTP value (Rp)

$\beta o \quad=$ Intercept

$\beta 1, \ldots, \beta 4=$ Regression Coefficient

$\mathrm{FU}=$ Age Factor (year)

LP = Education (year)

$\mathrm{PD}=$ Income $(\mathrm{Rp})$

$\mathrm{i} \quad=1$-respondent $(1=1,2, \ldots, \mathrm{n})$

\section{RESULTS AND DISCUSSION}

This research took place in Tapak Village, Tugurejo Urban Village, TuguSubdistrict, Semarang City. The area of Tugurejo Urban Village is $\pm 855,838 \mathrm{Ha}$. Divided into 3 elevations, namely lowland. In this research, characteristics of respondents varied greatly, both in terms of gender, age, education and total income. With a sample of 30 respondents, $80 \%$ were male and the remaining $20 \%$ were women. The age level of respondents in this study was varied, between 31 - 57 years, with an average age of 43.7 years. The highest number of respondents was at the age of $41^{-50}$ years as many as 19 people. The average duration of education in this study was 9.4 years, with the highest education being undergraduate and the lowest education was not graduating from elementary school. The average income of respondents is Rp. 1,851,666, with the highest income of more than Rp. 5,00o,ooo ( 1 respondent) and the lowest income is $<R p$ 500,000 . 
There are two scenarios offered to overcome pollution in the Tapak River, with complete details can be seen in Table 3 and Table 4.

Economic valuation to overcome pollution in the Tapak River (Contingency Method Analysis / (VM). The economic assessment carried out is an analysis used to determine the level of willingness to pay the people who live around the river to contribute to the prevention of pollution on the Tapak River. The calculation of economic valuation is carried out using the Contingent Valuation Method (CVM), which consists of willingness to pay (WTP) of people living around the river to spend the cost of making slow sand filtrations. Using the CVM method, commodities that do not have market prices, such as pollution levels, can be calculated. The following are the results of the implementation of the CVM method in this study:

First, setting up the hypothetical market - all respondents were given information and explained the importance of paying contributions as a contribution of the community to preserve the Tapak River. Therefore, community participation in maintaining the cleanliness of the river so that pollution can be reduced so that the benefits of the river can be felt by the next generation and with the aim of environmental sustainability.

Second, obtaining bids- in this research, the technique used to determine the value of the respondent's WTP is game bidding. The method of bidding game is applied by giving an offer value to respondents who are willing to pay. The game starts from the middle value when the respondent is willing to pay, then the offer will be raised. However, if the respondent does not want to choose the middle value, it will be lowered to the lower value until it reaches the WTP value desired by the respondent. Optimal bidding design will refer to the bid price and sample size which minimizes information about welfare measures. The maximum probability of estimation which has the potential to increase is greater. If the sample is small, but when the sample size increases it will decrease the bias proportionally. Estimates of pollution prevention costs on the Tapak River are based on interviews. The offer value scenario is divided into two as shown in Table 3. In scenario 1, offered the development of the Slow Sand Filtration which aims to filter tread river water contaminated by liquid waste from factories and the environment around the Tapak River ecosystem is maintained, in this study used an estimate of maintenance for one year.

The Slow Sand Filtration will be built with a length of 4 meters and width $(2 \mathrm{~m} \mathrm{x}$ $2 \mathrm{~m})$. To filter polluted river water, several components are used, namely: recharge fibers, fine sand, charcoal, gravel / split rock, large stones, wire mesh, settling tubs, and filter tanks. In the first year maintenance the components to be replaced are recharge fibers. The total cost needed to build the Slow Sand Filtration is Rp 80.850.00o. The fee will be borne by the community around Tapak River, by making annual fees of Rp 12.000 per year. It is expected that the development of the Slow Sand Filtration can reduce the level of water pollution in Tapak River. 
Table 3. Scenario 1 Tapak River Ecosystem Conservation for WTP in TapakTugurejo. Development of Slow Sand Filtration and 1 Year Maintenance

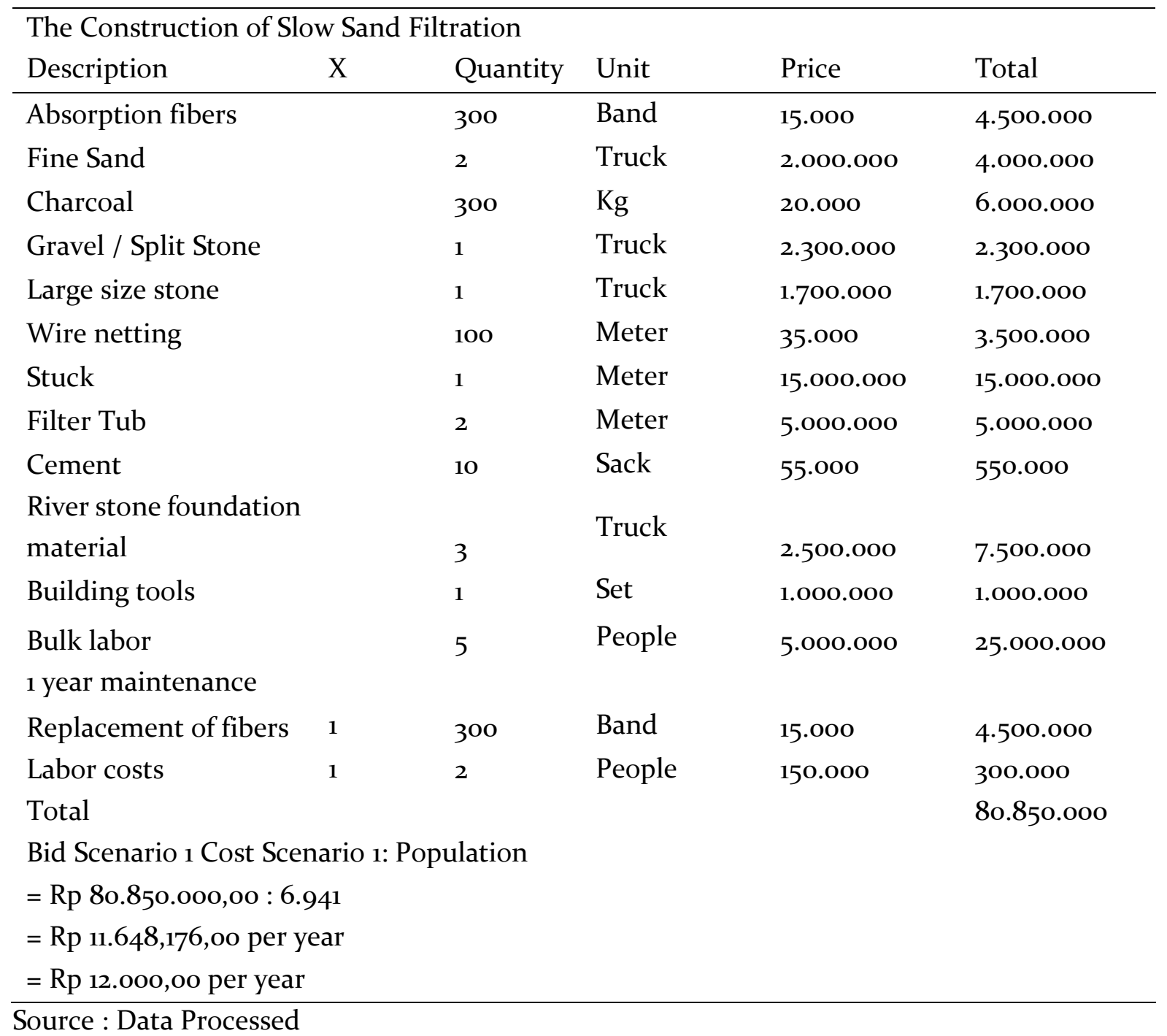

In this research, scenario 2 is also offered, namely the ecososystems in Tapak River stagnant organic and inorganic rubbish and those around the Tapak River, and offering management of simple waste banks for estimation of 1 year maintenance. For collection of rubbish that is pooled as well as that is around the Tapak River will be carried out by workers who will later be paid. Later the worker will walk along Tapak River using getek and the garbage will be put into the trash bag. For the management of a simple waste bank, then will be distributed as many as 30 barrels / drum of large trash as a waste dump for the surrounding community so as not to dispose of trash carelessly. The total cost of scenario 2 is $\mathrm{Rp} 139.350 .000$ per year, which will be borne by the surrounding community. If the community around Tapak River agrees with the existence of these two scenarios, the costs they have to pay are $\mathrm{Rp}$ 21.00o per year. 
Table 4. Conservation Scenarios 2 Collection of inorganic and organic solid waste in water and on land

\begin{tabular}{|c|c|c|c|c|c|}
\hline \multicolumn{6}{|c|}{ Collection of land and water waste } \\
\hline Description & $\mathrm{X}$ & Quantity & Unit & Price & Total \\
\hline Wages for garbage collectors & 24 & 20 & $\begin{array}{l}\text { Working } \\
\text { days }\end{array}$ & 50.000 & 24.000 .000 \\
\hline Rent Getek & 24 & 5 & Piece & 200.000 & 24.000.000 \\
\hline Trash Bag & & 240 & Piece & 25.000 & 6.000 .000 \\
\hline \multicolumn{6}{|l|}{ Simple waste bank management } \\
\hline Large trash can / drum & & 30 & Piece & 150.000 & 4.500 .000 \\
\hline Total & & & & & 58.500 .000 \\
\hline Scenario $1+2$ & & & & & 139.350.000 \\
\hline \multicolumn{6}{|c|}{ Bid Scenario 2, Bid $1+$ Bid 2 : Population } \\
\hline \multicolumn{6}{|c|}{ Cost Scenario $1+2:$ Population $=139 \cdot 350.000: 6.941=$ Rp. $20.076,358,00$} \\
\hline
\end{tabular}

The next scenario offered to deal with pollution in the Tapakriver is to use a scenario approved by collection of inorganic and organic solid waste in water and on land, The concervation scenario can be seen in Table 4. Construction of a beam-shaped slow sand filtration that extends downward, 4 meters in length and width ( $2 \mathrm{~m} \times 2 \mathrm{~m})$. The settling body is used to precipitate particles contained in the water.

A filter body is used to filter the water that has been deposited. Wages of labor collectors, the labor collector of garbage is the energy that is used to collect garbage both on the edge of the river and in the pool at times, garbage collection is done twice a month. Rent Getek, getek rental is used to take rubbish that is pooled on the rivers, 1 getek can fit 2 people. Simple bank waste management personnel are administrators who are paid monthly to take care of simple waste bank administration. Maintenance is carried out every 1 year, by replacing one layer of slow sand filtration and in the first year replaced is a layer of palm fiber.

Based on the interviews, 30 respondents stated that the water conditions in the Tapak River were exposed to pollution. There are three sources of pollution in the Tapak River, namely household waste, factory waste around the river, and human waste. The description of the results of interviews regarding sources of pollution in the Tapak River can be seen in Figure 2 and Figure 3.

Based on the illustration in Figure 2 it can be seen that as many as 13 people or $29 \%$ of respondents stated that the source of pollution in the Tapak River came from household waste. The majority of respondents as many as 29 people or $64 \%$ of respondents revealed the source of pollution in the Tapak River was caused by factory waste. Figure 3 shows that the majority of respondents were 22 people or $73 \%$ of respondents were willing to pay to support 
pollution prevention on the Tapak River. A total of 11 people or $36 \%$ of respondents were willing to pay a nominal value of $\mathrm{Rp} 10,000$. Meanwhile 6 people or $20 \%$ of respondents are willing to pay a nominal value of $\mathrm{Rp}$. 20,000.

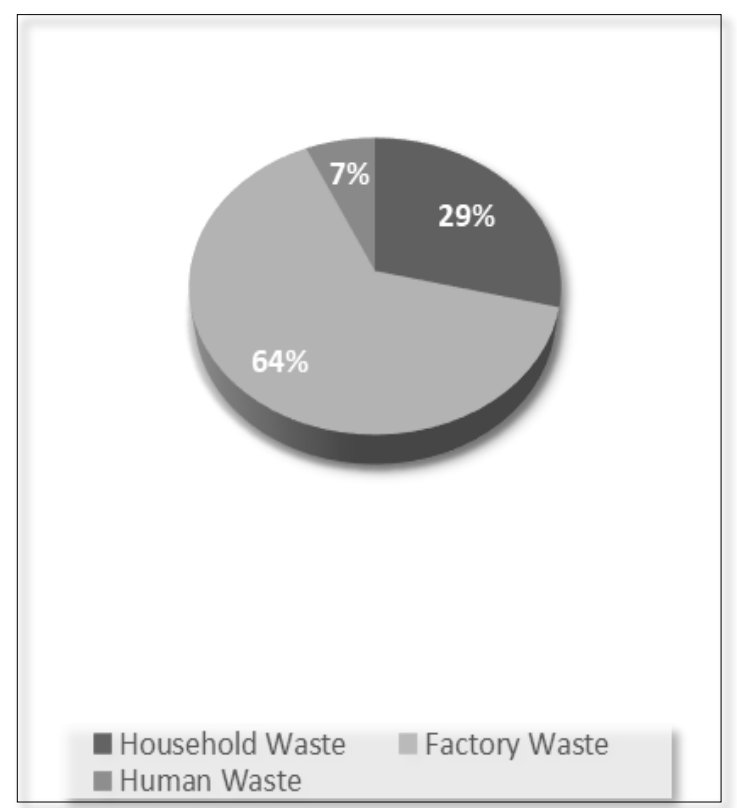

Figure 2. Source of pollution in the Tapak River

The remaining 5 people or $17 \%$ of respondents are willing to pay a nominal value of Rp. 15,00o. The reason people are willing to pay because of the pollution prevention on the Tapak River can minimize the occurrence of tidal flooding that often occurs during the rainy season. While the remaining $27 \%$ or 8 people are unwilling to pay for pollution prevention costs.

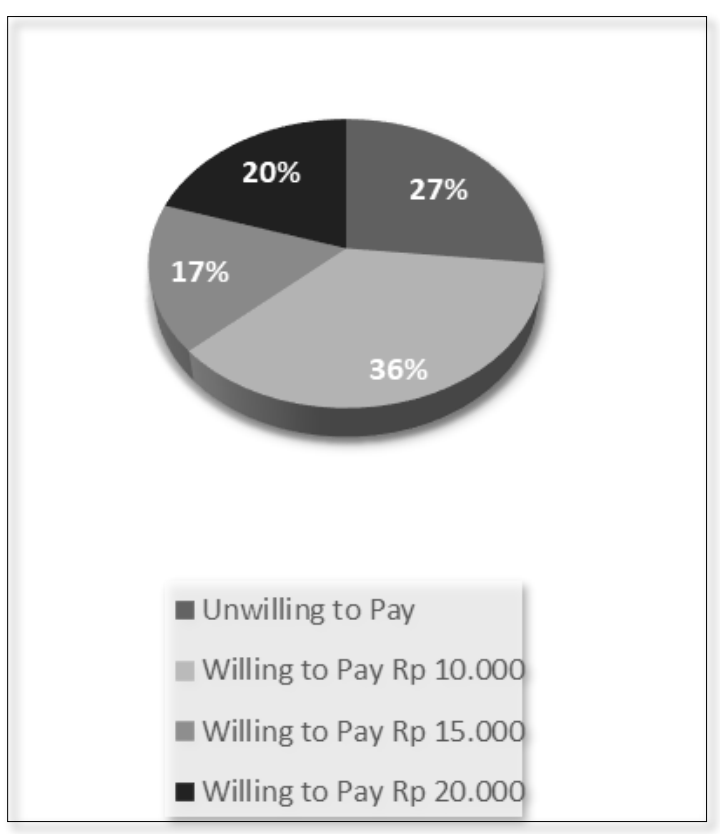

Figure 3. Willingness to Pay (WTP).

Third, calculating average WTP interviews using questionnaires were conducted to observe willingness to pay from respondents, and to find the value of WTP that must be paid. The results showed that most respondents stated "willing" about the application of the slow sand filtration on the Tapak River.

Table 5. Calculation of WTP

\begin{tabular}{llll}
\hline WTP & $\begin{array}{l}\text { Total } \\
\text { Respondents } \\
(\mathrm{w})\end{array}$ & $\begin{array}{l}\text { Total } \\
(\mathrm{n})\end{array}$ & $\begin{array}{l}\text { Peentase } \\
(\%)\end{array}$ \\
\hline Rp10.000 & 11 & Rp110.000 & 50.00 \\
Rp15.000 & 5 & Rp75.000 & 22.73 \\
Rp20.000 & 6 & Rp120.000 & 27.27 \\
\hline Total & 22 & Rp305.000 & 100.00 \\
\hline EWTP & & Rp13.864 & \\
\hline
\end{tabular}

Source : Data Processed 
When respondents were asked whether they would be willing to participate by paying dues according to the amount set. The average value of respondents' WTP is calculated based on the ratio of the number of WTP given by respondents and the total number of respondents who are willing to pay. Distribution of WTP respondents and total WTP in relation to efforts to maintain coastal cleanliness Tapak River. Based on Table 5, it can be seen that the lowest WTP value that the community is willing to pay is Rp 10,00o. While the highest value is $\mathrm{Rp}$. 20,000 . The average value of willingness to pay for pollution prevention efforts in the Tapak River, Tugurejo Urban Village is Rp. 13,864, or rounded up to Rp. 14,0oo. This price shows the value of the WTP close to the value of the scenario 1 response measures.The estimated total cost that is willing to be issued by the community in the effort to overcome pollution in the Tapak River is obtained through the elimination of the total WTP value. The aggregate value of the total WTP of community is obtained by multiplying the WTP value, which is Rp. 14,00o with a total population to get the total value of WTP of community in Tapak Village, Tugurejo Urban Village, TuguSubdistrict. Total population in this study is 6,941 . The results of calculating the total WTP are presented in Table 6. Last, aggregating data - the proposed average value in accordance with Table. Table 6 shows the total WTP of Tugurejo Urban Village, Tugurejo Subdistrict community in the efforts of pollution prevention in the Tapak River is valued at $\mathrm{Rp}$ 97.174.00o, this value is the total value for pollution prevention in the Tapak River using the slow sand filtration method.

Table 6. Calculation of TWTP Value

\begin{tabular}{lll}
\hline $\begin{array}{l}\text { Expected WTP } \\
\text { (EWTP) }\end{array}$ & $\begin{array}{l}\text { Population } \\
(\mathrm{N})\end{array}$ & $\begin{array}{l}\text { Total WTP } \\
(\text { EWTP } x)\end{array}$ \\
\hline Rp 14.000 & 6.941 & Rp 97.174.000 \\
\hline
\end{tabular}

Source : Data Processed

Based on Table 7, it can be seen that the value of $R$ square $\left(R_{2}\right)$ is 0.51 , indicating that the WTP value of $51 \%$ can be explained by variables in the model and the remaining $49 \%$ is explained by variables outside the model. In addition, it is known that the calculated F-value is 9,084504 with a Sig. of o,00o277, which means that the value of the resident's WTP to improve water quality in the Tapak River is influenced by the independent variables together. Based on the results of multiple linear regression tests, an equation model is obtained as follows

$$
\begin{aligned}
\mathrm{WTP}= & 2302,524+6,418 \mathrm{FUi}+47 \cdot 382 \mathrm{LPDi}+ \\
& \text { o,003Pdi }
\end{aligned}
$$

The multiple linear regression results show that the income variable has a significant value of 0.0003 , at the significance level $\alpha=5 \%$ and the coefficient value with a positive sign $(+)$ shows that income has a positive influence on the magnitude of the WTP value. This mean that the higher the income of the community, the higher the willingness to pay the community to deal with pollution in the Tapak River. 
Table 7. Test Regression of Factors that have an influence on WTP Value

The results of multiple linear regression tests

\begin{tabular}{llll}
\hline Variable & Coefficient & Sig. & Information \\
\hline Constant & 2302.524 & 0.7725 & $(-)$ \\
& & & No effect \\
Age & 6.418511 & 0.9686 & No effect \\
Education & 47.38290 & & \\
& & 0.9015 & Effecting Significantly \\
Income & 0.003855 & 0.0003 & $(-)$ \\
R & & & $(-)$ \\
F Statistic & 0.511769 & $(-)$ & $(-)$ \\
Durbin- Watson & 9.084504 & 0.000277 & \\
& 2.304942 & $(-)$ & \\
\end{tabular}

Source : Data Processed

This result is consistent with the research conducted by Annisa and Harini (2014) which shows that income has a positive effect on the value of WTP. The income of the population influences the value of the WTP because assuming the higher the income, the higher the funds allocated for other costs, in this case, to support the improvement of water quality on the Tapak RiverOther independent variables such as age do not have a significant effect on the value of WTP. This is indicated by the significance value of age is 0.9686 which is greater than the significance value of 0.05 . This result is supported by research conducted by Ladiyance and Yuliana, where the results obtained indicate that age does not significantly influence the value of WTP that the community wants to pay. The condition of the Tapak River which is polluted by liquid waste from factories both upstream and downstream, is exacerbated by the bad habits of people who throw garbage at random - further worsening the situation. There are two scenarios offered in this study. Scenario one offers the development of slow sand filtration, which will be built in the lower reaches of the Tapak River. The development of the slow sand filtration aims to filter Tapak River water polluted by industrial waste so that river water can be used to irrigate rice fields and irrigate ponds without causing losses to farmers and fishermen. While the second scenario offers cleaning of waste in the Tapak River and the management of waste banks, with the aim of cleaning the river from garbage and inviting the surrounding community to dispose of garbage in its place so that the river is clean.

\section{CONCLUSION}

Based on the results of the survey and analysis of willingness to pay, it can be concluded that pollution on the Tapak River is caused by 
factory waste, household waste, and human waste. There were 22 respondents from 30 respondents who were willing to pay to support the prevention of the Tapak River pollution in Tugurejo. The rate that is willing to be paid by the community is Rp 14,000.00. In this study, there was a total population of 6,941 people, which resulted in a total calculation of WTP for the effort to overcome Tapak River pollution by Rp 97,174,00o.oo. The results of the analysis also show that the amount of income is a factor that influences the value of WTP. Whereas age and education are factors that do not affect the value of community willingness (WTP) in the context of pollution prevention on the Tapak River.

\section{REFERENCE}

Agus Sistyanto, Niko. (2011). Domestic Water Use and Willingness To Pay Clean Water PDAM in Temanggung Subdistrict, Temanggung Regency. Jakarta: Universitas Gajah Mada.

Annisa, Tri Mulia and Rika Harini. (2014). Analysis Willingness to Pay for the Transfer of Sustainable Ecotourism in the Pindul Cave Tourism Area, Gunung Kidul Regency

Asdak, C. (2002). Hydrology and Management of Watersheds. Gajahmada University Press. Yogyakarta.

Bungin, Burhan. (2006). Quantitative Research Methodology: Communication, Economics, and Public Policy and Other Social Sciences. Jakarta: Kencana

Choe, K., D. Whittington and D. T. Lauria. (1996). The Economic Benefits of Surface Water Quality Improvements in Developing Countries: A Case Study of Davao, Philippines. Land Economics 72(4):519-37. Cochran, W. G. 1977. Sampling Techniques . 3rd ed. New York: John Wiley.

Effendi, H. (2003). Review of Water Quality. Kanisius Publisher. Yogyakarta.

Elfa M, Guty. (2009). Willingness To Pay Analysis of Society for Improving Service of Water Supply System with WSLIC (Water Sanitation for Low
Income Community). Bogor: Institut Pertanian Bogor.

Fauzi, Akhmad. (2010). Natural Resource Economics and the Environment: Characteristics and Applications. Jakarta: Gramedia Pustaka Utama

Greene, W. H. (2012). Econometric Analysis International Edition. 7th ed. New Jersey: Pearson Prentice Hall.

Gujarati, Darmodar N.(2003). Basic Econometrics. Fourth Edition. Singapore: McGraw-Hill, Inc.

Ghozali, Imam. (2009). Econometrics, Theory, Concepts, and Applications with SPSS 17. Semarang: Badan Penerbit Universitas Diponegoro.

Government Regulation No. 82 2001. concerning Management of Water Quality and Water Pollution Control. Ministry of Environment. Jakarta.

Hanley, N. and C.L. Splash. (1993). Cost of Benefit Analysis and the Environment. Chelthenham: Edward Elgar Publishing Ltd.

Han, Fang., Yang, Zaophing., Wang, Hui \& Xu, Xiaoling. (2011). Estimating Willingness to Pay for Environment Conservation : a Contingent Valuation Study of Kanas Nature Reserve, Xianjiang, China. Springer- Environ Monit Asses 180: 451-459.

Jatnika, Luthfan and Benno Rahardyan. (2015). Analysis Willingness To Pay Society Regarding Payment of Environmental Services for the Cirahab Springs (CurugGoong, Sub-district Padarincang, District Serang, Banten). 17(1):059-066

Karytsas, spyridon. Polyzou ,olympia. And Constantine karytsas. (2019). Factors affecting willingness to adoupt and willingness to pay for a residential hybrid system that provides heating/cooling and domestic hot water. Renewable energy. https://doi.org/10.1016/j.renene.2019.04.108

Kelurahan Tugurejo. (2018). Profile of Kelurahan Tugurejo. http://kectugu.semarangkota.go.id/kelurahantugurejo.

Ladiyance, Selfia and Lia Yuliana. (2014). Application of Contingent Valuation Method in Efforts to Improve Cikapundung River Cleanliness in Bandung City. 2(2).

Losonci, Ildiko. (2012). Valuation of Ecosystem Services : The Case of Orseg National Park, Hungary. (Thesis Master of science, University of New Hampshire).http://search.proquest.com.

Manik, K. (2003). Management of The Environment. Djambatan Publisher. Jakarta.

Merryna, Annisa. (2009). Analysis Willingness To Pay for 
HippamCangar User Against Gemulo Springs.

Mitcell, Robert C. and Ricard T Carson. (1989). Using Surveys to Value Public Goods: The Contingent Valuation Method. Washington, D.C: Resources for the Future.

Ningrum, Hardian Cahya. (2017). Variables that Affect Willingness To Pay in Bidaracina Society, East Jakarta. 25(2).

Nam, P. K, and T. V. H. Son. (2005). Household Demand for Improved Water Services in Ho Chi Minh City: A Comparison of Contingent Valuation and Choice Modelling Estimates. The Economy and Environment Program for South East Asia (EEPSEA). Singapore.

Nazir M. (2005). Research Method. Jakarta: Ghalia Indonesia.

Pineda, F.P dan Armijo, C.Q. (2013). Estimating Willingness To Pay and Financial Feasibility in Small Water Projects in El Salvador. Journal of Business Research 66 1750-175

Raje, DV.,Dhobe, PS., Deshpande, AW. (2002). Consumer's Willingness To Pay More for Municipal Supplied Water: A Case Study. Ecological Economics, 42.

Ramdas, Murugadas \& Mohamed, Badaruddin. (2014). Impacts of Tourism on Environmental attributes, environmental literacy and willingness to pay : a Conceptual and Theoritical Review. Procedia- Journal of Social and Behavioral Sciencess, 144(1), 378391.

Salmin. (2005). Dissolved Oxygen (DO) and Biological Oxygen Needs (BOD) As One Indicator To Determine Quality of Fisheries. Field of Ocean
Dynamics Oceanographic Research Center-LIPI, Jakarta.

Saptutyningsih, Endah. (2007). Influential Factors Against Willingness to Pay for Improving the Quality of the Waters of the Code River in the City of Yogyakarta. 8(2):17

Saptutyningsih, Endah. Selviana, Rini. (2017). Valuing Ecotourism of a Recreational Site in Ciamis District of West Java, Indonesia. Jejak 10(1):172-188. http://dx.doi.org/10.15294/jejak.v1oi1.9134

Statistics of Semarang Municipality. (2018). Tugu Subdistrict in Figures 2017. Semarang: CV. Citra Yunda

Statistics Indonesia. (2019). Status of River Water Quality2007-2016. https://www.bps.go.id /statictable/2014/o9/05/1372/status-kualitas-airsungai-2007---2016.html/.

Schroeder, E. D. (1997) Water Wastewater Treatment. McGraw-Hill, Ich.

Sugiyono. (2012) Research Method Qualitative Quantitative and Researh \& Development. Bandung: Alfabeta

Susilowati, Indah. FerdinanSyah, Angga. Suharno. And JakaAminata. (2018). Economic Valuation of Tourism Attraction of Jatijajar Cave in Kebumen Regency. Jejak 11(1):12-28. https://doi.org/10. 15294/jejak.vi1i.13523

Whittington, D., Briscoe, J., Mu, X., Baron, W.. (1990). Estimating the Willingness to Pay for Water Services in Developing Countries : A Case Study of the Use of Contingent Valuation Surveys in Southern Haiti. Economic Development and Cultural Change, 38(2).

Yakin, A. (1997). Natural Resource Economics and Environment Theory and Wisdom of Sustainable Development. Jakarta: CV Akademika PressIndo. 